\title{
Genevieve Naylor, fotógrafa: impressões de viagem (Brasil, 1941-1942)1
}

Ana Maria Mauad²

\section{RESUMO}

Genevieve Naylor fotografa o Brasil, em 1941 e 1942, sob os auspícios do Office of Inter-American Affairs (OIAA), órgão dirigido por Nelson Rockefeller e responsável pela implementação da Política da Boa Vizinhança. Em 1943, Naylor é convidada a expor no Museu de Arte Moderna de Nova York (MoMA) e, depois, em vários museus dos Estados Unidos, suscitando diferentes impressões. Naylor formou-se influenciada pela geração de fotógrafos que nos anos 30 transformaram a imprensa ilustrada no principal meio de acesso ao mundo, e viajou como funcionária do governo de seu país, tendo de cumprir protocolos fotográficos bem definidos. O resultado desse jogo de influências é um conjunto de fotografias analisadas neste artigo buscando compreender o seu impacto na conformação de uma certa imagem de Brasil para os "vizinhos" norte-americanos.

Palavras-chave: Política da Boa Vizinhança; Fotografia; Viajantes.

\section{ABSTRACT}

In 1940, the photographer Genevieve Naylor and her companion Misha Reznikoff, an artist, were sent to South America by Nelson Rockefeller's Office of Inter-American Affairs (OIAA), the wartime agency organized to cultivate Latin American support for allies. Brazil was their destiny and her mission was to create an image from Brazil to USA audience. Her photos depict Brazil during those years in considerable detail enlarging the official purpose of her visiting by a really concerned approach to Brazilian reality. On her return from Brazil, Naylor had a successful onewoman show at New York's Museum of Modern Art (MoMA) in 1943. This article discuss the narrative created by Genevieve Naylor's photos during her travels throughout Brazil.

Keywords: Good Neighbor Policy; Photographs; Travelers. 
Life é a única revista que eu conheço que distrai pela falta de assunto. A gente passa aquilo como criança passa livro de figuras, constatando rapidamente a aparição de uma curiosidade ou outra: 'totó', 'neném', 'fon-fon', e assim por diante.

Mas é impossível resistir-lhe à fotografia. Quem por acaso, já teve ocasião de conhecer algum fotógrafo de Life, sabe perfeitamente disso. São criaturas de conto de fadas, capazes de lambuzar de caramelo toda uma 'panzerdivisionem', verdadeiros gênios do instantâneo, sabedores de todas as infantilidades da alma grande. Eu já conheci dois, sendo que em ambos senti esse mesmo adejamento endiabrado, uma mesma alegria de vaga-lume que vai queimando as suas lâmpadas sobre as coisas surpreendidas. Um deles é uma americanazinha adorável que se acha aqui no Rio. Genevieve se chama, mulher desse grande Micha que conquistou a nossa pequena cidade artística com a sua simpatia e sua sensibilidade plástica.

Genevieve parece ter saído de uma história de Robin-Hood, com seu arzinho de jovem pajem, sua elegância bem colorida, uma pena sempre atrevidamente espetada no chapéu. Nada escapa, no entanto, à maquinazinha dessa enfeitiçada. Perto dela não há momento fotográfico que passe sem cair naquela arapuca bem armada. Genevieve dá um pulinho - e a vida ali ficou batendo asa na sua chapa impressionada.

Vinícius de Moraes, "A Última Catedral", A manhã, Rio de Janeiro, 19.10.1941

O fascínio do então cronista e crítico de cinema, Vinícius de Moraes, pelas imagens sensíveis de Genevieve Naylor, revelam a presença ambígua e sempre marcante dos Estados Unidos no Brasil, e por extensão na América Latina, como um todo. As imagens visuais - fotográficas. cinematográficas e publicitárias - sedimentaram a ponte pela qual a aproximação cultural entre as Américas se realizou. ${ }^{3}$

Mas, o que está em jogo na elaboração da chave de leitura histórica para se compreender as fotografias produzidas no Brasil por Genevieve Naylor, durante sua permanência entre 1940-1942, como funcionária do Office of the Coordinator of Inter-American Affairs (CIAA)? Por um lado, no contexto da Política da Boa Vizinhança o crescente interesse de intelectuais e artistas nor- 
te-americanos pelo Brasil e a ampliação das trocas culturais (Portinari, as exposições artísticas norte-americanas no Brasil, a criação do MAM/RJ). Neste aspecto, o contexto norte-americano delimitava-se pela experiência da depressão econômica dos anos 30, pelo crescimento urbano, pelas experimentações das vanguardas artísticas e pelas instituições criadas no âmbito do Estado de bem-estar social - o New Deal de Franklin Delano Roosevelt. Além disso, havia o declarado interesse, por parte do Departamento de Estado dos EUA, em consolidar a presença norte-americana na América Latina através de acordos comerciais, planos de cooperação internacional e, por fim, de alianças políticas que garantissem a hegemonia dos Estados Unidos na região.

Nesse sentido, para analisar a mensagem fotográfica elaborada pela fotógrafa durante a sua permanência no Brasil, pretendo, primeiramente, relacionar a produção brasileira de Genevieve Naylor com a tradição da fotografia documental norte-americana, ao mesmo tempo em que aponto os diálogos que são travados com a cultura visual elaborada pela agência oficial da Política da Boa Vizinhança: Office of the Coordinator of Inter-American Affairs (CIAA).

Definido os quadros de significação histórica que conformam o conjunto possível de escolhas para a fotógrafa, parto para a análise dos elementos da forma da expressão e do conteúdo da mensagem fotográfica, enfatizando os dois aspectos mais marcantes da sua narrativa visual:

$1^{\circ}$ como a figuração humana é retratada, entendendo as representações do corpo como suporte de relações sociais. O corpo representado nas fotografias de Naylor é o signo, através do qual as relações sociais se revelam;

$2^{\circ}$ como os lugares por onde Naylor viajou foram figurados na elaboração de uma geografia sensível que busca transgredir os protocolos oficiais, para mostrar um Brasil múltiplo.

Nesse sentido, Naylor mais do que conformar uma imagem do Outro, através dos protocolos etnográficos da alteridade, em suas imagens define esse Outro pela sua condição humana. Investe muito mais nas possibilidades de se estabelecerem nexos comuns, do que em criar diferenças impenetráveis (ou acessíveis somente pelo discurso científico da etnografia). A forma de compor suas fotografias revela o diálogo que a fotógrafa estabeleceu com as referências visuais de seu tempo. Principalmente aquelas associadas à produção artística dos anos 30, cuja valorização do indivíduo se fazia em consonância ao papel por ele desempenhado nas relações sociais. 
O resultado da conjugação dessas referências foi a elaboração de uma alteridade plural dos brasileiros e brasileiras — jovens, crianças e velhos possível de ser apreendida pela gente comum dos Estados Unidos, o público alvo das suas fotografias.

\section{Notas Sobre a Política da BoA VizinhançA ENTRE BRASIL E EUA NOS ANOS 40}

A doutrina do destino manifesto foi a base sobre a qual a cultura política norte-americana cunhou sua auto-imagem, fundamental para a elaboração do mito americano. Um mito que tinha como missão espalhar os verdadeiros sentimentos da América, através dos seus sonhos de perfectibilidade. Tal estratégia pautava a política externa norte-americana numa moral que concebe a América do Norte como o local da perfeição e que compreende a sua intervenção, em outras regiões do mundo, como a tentativa de estender tal perfeição. Os pilares desse sonho de perfectibilidade seriam a Democracia e a Liberdade introduzidas pela homogeneização cultural, ${ }^{4}$ como mais um produto a ser consumido.

Naylor chega ao Brasil em outubro de 1940, como funcionária do Departamento de Estado norte-americano, mais especificamente do Office of the Coordinator of Inter-American Affairs (CIAA), então dirigido pelo milionário Nelson Rockefeller, órgão criado pelo governo de F. D. Roosevelt para garantir a solidariedade latino-americana para a causa liberal diante da expansão do nazifascismo, ao mesmo tempo em que criava uma área de reserva de mercado para os produtos norte-americanos durante a Segunda Guerra Mundial.

Criado em 16 de agosto de 1940, inicialmente para garantir e ampliar as bases das relações comerciais entre as Américas, esse órgão recebeu o nome de Office of Commercial and Cultural Relations between the American Republics, passando a se chamar, a partir de 30 de julho de 1941, Office of the Coordinator of Inter-American Affairs, e em 23 de março de 1941, já dirigido por Nelson Rockefeller, Office of Inter-American Affairs, até o seu fechamento em 20 de maio de 1943. As mudanças de nome traduzem as redefinições em relação à forma como a política internacional norte-americana deveria se estabelecer com o restante das Américas, ampliando sua ação intervencionista para diferentes áreas além da estritamente comercial.

Independentemente do nome que assumia, esse órgão tinha como fun- 
ção implementar a Política da Boa Vizinhança norte-americana na América Latina, que consubstanciava uma solidariedade hemisférica definida, nos termos dos interesses norte-americanos. Aliás, como já vinha sendo feita a política externa dos Estados Unidos para a América Latina, desde fins do século XIX, através de sucessivas posturas intervencionistas: da doutrina Monroe América, para os americanos, seguida pelo Big Stick, até chegar ao pan-americanismo da Segunda Guerra Mundial, inaugurado por Franklin Delano Roosevelt em 1933.

$\mathrm{Na}$ avaliação do historiador norte-americano Frederick Pike, a política de não intervenção era o princípio da realpolitik de Roosevelt para o continente americano. Por um lado, pressionava seus antigos parceiros, entre os quais a Inglaterra, a abandonar sua postura imperialista, em prol de um mundo mais pacifico, no qual os interesses dos Estados Unidos pudessem ser garantidos; por outro, reconhecia a existência dos princípios políticos, econômicos, morais e culturais próprios à América Latina, sem impor o abandono destes em prol do, cada vez mais popular, american-way-of-life.

Na perspectiva do presidente norte-americano, a Política da Boa Vontade levaria os latino-americanos a abraçarem naturalmente a causa americana, defendida pelos Estados Unidos. No entanto, como reforça Pike, para Roosevelt os latino-americanos deveriam crescer ainda muito, para se ajustarem aos padrões culturais dos Estados Unidos.

Em linhas gerais, a solidariedade hemisférica visava garantir a posição estratégica dos aliados no Cone Sul, a partir do avanço das forças do eixo no Pacífico. O ataque a Pearl Harbour, em 1941, foi fundamental para deslanchar de maneira mais agressiva a colaboração entre os países americanos, obrigando muitos governantes, entre os quais Getúlio Vargas, a uma definição política mais clara e cooperativa.

Em termos de estruturação, em todos os países da América Latina nos quais o CIAA abriu um escritório de representação, estabeleciam-se metas prioritárias de ação. No Brasil as três metas eleitas foram: informação, saúde e alimentação. Esses três setores tinham funções definidas de penetração e convencimento ideológico através do controle dos meios de comunicação, investimento intensivo em publicidade e fomento de uma estrutura assistencialista para a saúde e educação, principalmente no Nordeste, em áreas onde seriam instaladas as bases norte-americanas.

Paralelamente, o CIAA através de acordos com instituições culturais norte-americanas, como o Museu de Arte Moderna de Nova York, também sob a direção de Rockefeller, passa a fomentar o intercâmbio cultural através de di- 
ferentes modalidades de incentivo tais como: bolsas de estudo para artistas latino-americanos irem aos Estados Unidos estudar, exposições arqueológicas, de pintura moderna, de arquitetura, além dos festivais de música latinoamericana, todos realizados dentro do MoMA. ${ }^{5}$

Em agosto de 1940 Candido Portinari expõe seu trabalho no MoMA, cercado de comentários sobre a compra de seus quadros pela instituição e de reportagens sobre o Brasil, em todos os jornais norte-americanos. A aceitação da arte brasileira nos Estados Unidos integrava a estratégia política de valorização da cultura brasileira. Valorizavam-se, nas salas de exposição do MoMA, as expressões culturais que apresentassem aos Estados Unidos um Brasil culto e moderno, em consonância com os projetos das frações da classe dominante, detentoras do poder político e econômico. Enquanto isso, na Broadway Carmen Miranda brilhava em Streets of Paris - mas Carmen era uma face do Brasil que desagradava ao verniz cosmopolita da elite. No entanto, Carmen e Portinari eram o Brasil, para os norte-americanos.

Nesse sentido, a moeda cultural foi o investimento simbólico para a aproximação dos dois países. Uma forma de convencer os norte-americanos da amizade brasileira e, ao mesmo tempo, incentivar as autoridades brasileiras a escolher o 'lado certo' na guerra.

Os articuladores da política externa norte-americana tinham certeza da expansão do nazismo no Brasil, a ponto de num relatório a Rockefeller, W. Guest, funcionário oficial da política externa norte-americana para o Brasil, afirmar: "Eu considero que o Brasil é a mais importante e a mais perigosa de todas as Repúblicas do Sul, e estou convencido de que os alemães também pensam isso. Todos os homens de seu governo são abertamente pró-nazi, com exceção do presidente Vargas e de Oswaldo Aranha". ${ }^{6}$

Para Guest, Vargas se comportava de forma oportunista e, se na hora $\mathrm{H}$ a vitória pendesse para o lado alemão, ele não teria dúvidas em aderir. Guest chegou a contatar Décio de Moura, secretário particular de Oswaldo Aranha. E anota que o chefe de polícia era Filinto Muller, pró-nazi, e Lourival Fontes era o "ministro da propaganda e um estudioso leitor de Goebbels"; além de Montero [sic, Góis Monteiro], ministro de Exército que "também admira os alemães".

Dentro da perspectiva de Rockefeller, o fundamental seria fomentar no Brasil, e no restante das Américas, a criação de canais culturais que permitissem o intercâmbio efetivo com os Estados Unidos. O Museu de Arte Moderna do Rio de Janeiro foi criado nos moldes do seu equivalente norte-americano, seguindo as determinações da $3^{\underline{a}}$ reunião de consulta realizada nessa 
cidade, em 1940. De acordo com as negociações feitas entre a Sra. Lucia Fonseca, representante brasileira, e Nelson Rockefeller, o Museu deveria coletar e adquirir obras de arte moderna, bem como de arte popular brasileira, além de investir no intercâmbio artístico entre os povos americanos. De acordo com o documento de criação do MAM, a instituição seria um dos pilares de defesa da civilização ameaçada, bem como da união das Américas. ${ }^{8}$

O representante norte-americano para a criação do MAM foi, justamente, Misha Reznikoff, companheiro de Genevieve Naylor nas suas peregrinações pelo Brasil, e artista plástico de origem ucraniana que fez sucesso, aqui, com seus "Monstros da Guerra". Naylor e Reznikoff, seguidos por Orson Welles e Waldo Frank, formam o lado intelectual e sensível do imperialismo sedutor - para usar a feliz expressão de Pedro Tota ${ }^{9}$ — que domina o Brasil nos anos 40 .

Foi nesse contexto que os brasileiros aprenderam a substituir os sucos de frutas tropicais onipresentes à mesa por uma bebida de gosto estranho e artificial chamada Coca-Cola. Começaram também a trocar sorvetes feitos em pequenas sorveterias por um sucedâneo industrial chamado Kibon, produzido por uma companhia que se deslocara às pressas da Ásia, por efeito da guerra. Aprenderam a mascar uma goma elástica chamada chiclets e incorporaram novas palavras que foram integradas à sua língua escrita. Passaram a ouvir o fox-trot, o jazz e o boogie-woogie, entre outros ritmos, e assistiam agora a muito mais filmes produzidos em Hollywood. Passaram a voar nas asas da PanAmerican, deixando para trás os "aeroplanos" da Lati e da Condor. ${ }^{10}$

No entanto, as imagens de Naylor revelam aos olhos dos norte-americanos um Brasil que mistura essa cultura urbana internacionalizada com a outra, atávica, das profundezas do sertão. Na sua viagem pelo Brasil une o litoral ao interior, numa síntese inusitada que até hoje causa estranhamento em quem a vê. Qual a mágica de Genevieve?

\section{Os INGREDIENTES DA MAGIA: TRAJETÓRIA DE GENEVIEVE NAYLOR}

Ao longo das primeiras três décadas do século XX, a produção fotográfica norte-americana foi marcada por duas tendências - a camera work, de Alfred Stiglitz, tendência pictorialista; e o social work, de Louis Hine, a tendência de se operar a câmera fotográfica como uma arma de denúncia social. Duas tendências que dividem o campo fotográfico, em termos de postura po- 
lítica, mas que dialogam em termos de linguagem e de exercícios estéticos. ${ }^{11}$ Dentro desse contexto Genevieve Naylor define-se como fotógrafa.

Genevieve Hay Naylor nasceu em 2 de fevereiro de 1915, em Springfield, Massachusetts. Seus pais, Emmett Hay Naylor, um promissor advogado de Boston, e Ruth Houston Cadwell, pertencente à elite local, separaram-se quando ela tinha somente 10 anos, em 1925.

Criada nos padrões da alta burguesia do Leste, desde cedo, como sua mãe, tentou romper com os padrões estabelecidos, estudando desenho e pintura numa escola local, e assim apaixonou-se pelo professor, Misha Reznikoff. Em 1933 muda-se para Nova York seguindo seu amor e seu instinto artístico. Lá, continua com seus estudos em pintura até que, em 1934, depois de ver uma exposição de fotografias que reunia nomes como Berenice Abbott, Eugene Atget e Henri Cartier-Bresson, muda o seu foco de interesse, passando a dedicar-se à fotografia. Seu destino: a New School for Social Research, onde Berenice Abbott ensinava. Iniciava-se, então, uma amizade que só iria se interromper com a morte de Naylor, em 1989.

Convivendo com Abbott, Genevieve Naylor tem a oportunidade de entrar em contato com os fotógrafos da Grande Depressão Norte-Americana, organizados na Farm Security Administration e coordenados por Roy Stryker, e com os temas candentes da época: justiça social, integração racial, antifascismo e cultura de vanguarda. A fotografia urbana do nova-iorquino Weegee e as tomadas arriscadas de Robert Capa logo passam a integrar o conjunto das suas preferências fotográficas. Misturando-se a essas influências a sua formação nas artes plásticas, o resultado foi um olhar sensível aos temas sociais, mas também treinado na estética visual das formas plásticas, dos claros-escuros, das linhas e das composições.

Em 1937, quando tinha 22 anos, foi recomendada pela liga profissional de fotógrafos para integrar o Work Progress Administration (WPA), instituição governamental criada na época da Grande Depressão para abrigar o trabalho de artistas. No WPA, Naylor fotografa, em diferentes cidades norteamericanas, temas de caráter social. Daí para o fotojornalismo é uma questão de tempo.

Nessa época as revistas ilustradas eram as janelas para o mundo, a visualização do que se ouvia nas rádios. Exerciam uma forte influência na cultura urbana de então e eram um grande canal para a expressão fotográfica de profissionais de peso. Em 1939 a jovem já integrava a Associated Press, como a primeira fotógrafa norte-americana a assumir função numa agência de notícias. Suas fotos passam a circular em importantes revistas internacionais, en- 
tre as quais Life, Time e Fortune. Aliás, foi nas páginas da Life que Vinícius de Moraes identificou a habilidade de Naylor.

A sua projeção no fotojornalismo chamou a atenção de Rockefeller, este sim, um caçador de talentos para implementar o destino manifesto norteamericano, a unificação cultural das Américas. É interessante questionar como Naylor, jovem culta, bem-sucedida na sua profissão, integrada numa Nova York boêmia e vanguardista, fosse assumir de forma inquestionável a retórica da união das Américas, defendida pelas agências governamentais. Claro que a luta antifascista unia pontas distintas do pensamento liberal norte-americano - desde os intelectuais comprometidos com uma tendência mais socialista, como Aldo Frank, até Walt Disney, um digno representante da industria cultural —, e foi justamente esse largo espectro ideológico que transformou a "invasão" cultural norte-americana em algo tão ambíguo quanto convincente.

No entanto, ao contrário do que apostava a geração de intelectuais, formada no ambiente do pluralismo cultural de Franz Boas, cuja referência máxima para a América Latina foi Waldo Frank, a união das Américas foi mais uma utopia. Os Estados Unidos, ao final da Segunda Guerra Mundial, como aponta Frederick Pike, voltaram à sua trilha familiar, a perseguir o progresso pelo progresso, a sua tradicional intolerância em relação aos povos e culturas ditos 'primitivos', por estes não deificarem os valores do individualismo burguês e do crescimento econômico a qualquer custo. ${ }^{12}$

É nesse quadro contraditório que podemos entender o fato de Naylor, digna representante de uma tendência denominada concerned photographs, ${ }^{13}$ aceitar o trabalho de fotógrafa da Boa Vizinhança.

\section{Vivendo E FOtOGRAFANDO, GENEVIEVE E Misha NO BRASIL}

Naylor chega ao Brasil em outubro de 1940, e, para realizar seu trabalho de fotógrafa, precisou obter um salvo-conduto assinado pelo diretor geral do Departamento de Imprensa e Propaganda, o DIP, órgão censor e repressor das atividades culturais no Brasil. A morosidade da burocracia fez que o passe necessário só tenha sido emitido em 1942, como se registra no documento acompanhado de sua foto: "A senhora Genevieve Naylor, de nacionalidade norte-americana, trabalhando para o Coordinator of Inter-American Affairs, está autorizada por este departamento a tirar fotografias de aspectos turísticos de nosso país. Rio de Janeiro, 7 de junho de 1942”. ${ }^{14}$ 
Levando-se em consideração que muitas das fotos de Naylor no Brasil são de 1941 e 1942, e que a fotógrafa retorna aos Estados Unidos em agosto de 1942, boa parte do seu trabalho foi realizada sem esse passe. No entanto, não foi somente esta a dificuldade encontrada por ela. Nas cartas que enviou à sua irmã reclamava da resistência por parte das autoridades, tanto brasileiras quanto norte-americanas, em registrar o que ela queria - além de películas - , por conta da guerra. Numa de suas cartas, endereçada à irmã, registrou tal escassez: "O filme está sendo racionado para todos ... eu não posso me dar ao luxo de fotografar tudo o que quero. Eu tenho de ter um maldito cuidado na hora de escolher as minhas imagens e torcer para que a exposição tenha sido calculada corretamente". ${ }^{15}$

Tanto o DIP quanto o OCIAA contrataram fotógrafos para registrar imagens positivas do Brasil, como forma de propaganda nacional e internacional. Além de Naylor, mais dois fotógrafos norte-americanos registraram imagens do país: G. E. Kidder Smith, especialista em fotografar arquitetura e responsável pelas fotografias do livro do arquiteto Philip L Goodwinn, Brazil Builds, que também deu título à exposição do fotógrafo no MoMA, da qual as fotografias de Naylor foram o complemento (como veremos adiante); e Alan Fisher, integrante da divisão de Saúde Pública e Higiene do OCIAA, que se concentrou nas condições médicas e instalações militares na região amazônica. ${ }^{16}$

Assim que chegou ao Rio, Naylor recebeu instruções claras do DIP sobre o que deveria fotografar. O documento indicava que a fotógrafa deveria valorizar alguns temas, entre os quais: arquitetura moderna (principalmente prédios governamentais); casas dos bairros nobres, como Lagoa, Gávea e Ipanema; interior de casas importantes e elegantes, no bairro do Flamengo; os domingos de sol nas praias de Copacabana e Ipanema; as corridas de cavalo no Jockey Club; os veleiros e iates na baía de Guanabara; o comércio exclusivo da rua do Ouvidor e as obras de caridade da Primeira Dama, D. Darcy Vargas. ${ }^{17}$

Instalado no Rio de Janeiro, o casal Naylor e Reznikoff passou a morar no Leme, bairro litorâneo, junto a Copacabana, onde Naylor registrou boas imagens do cotidiano praieiro, nada sem domingos de sol, num clima muito mais intimista, de quem acaba se perdendo entre as próprias imagens, misturando-se com a população local.

Tal efeito foi percebido por Aníbal Machado, crítico e escritor que sobre Genevieve Naylor afirmou:

Via-a saindo pela madrugada ou à noite, indiferente às intempéries, obstinada na realização de seu trabalho ... Mais que a excelência técnica, o que é preciso 
louvar nos trabalhos de Miss Genevieve é o sentido sociológico com que ela utilizou a objetiva, revelando um espírito corajoso e sincero, e, não raras vezes, comovido diante da realidade brasileira ... Os assuntos populares, humildes, os tais elementos essenciais que compõem a fisionomia do nosso povo são captados, pela fotógrafa da Boa Vizinhança. Mas sua maneira de fixar a realidade nada tem de monumental. Nada de cachoeiras, de edifícios monumentais, de paisagens idílicas. Sua visão poético-sarcástica por vezes evoca a arte sul-realista. [sic] Um país - o Brasil — captado então na sua força real: assim, no carnaval, a alegria é antes uma vibração convulsiva da tristeza que procura atordoar-se... como se estivesse procurando o resumo etnográfico. Importante o olhar, a percepção das imagens simples, que permite a recuperação dos tempos históricos acomodados no cotidiano, mas que resgata a vida de cada um em sua profundidade e intensidade. Não raro surge uma imagem agônica, áspera porém silenciosa, sempre densa. "Nada de cachoeiras...".

O casal freqüentou o apartamento de Machado em Ipanema, ponto de encontro de jornalistas, críticos, poetas e músicos, um ambiente bem parecido com aquele que Misha e Genevieve freqüentavam em Nova York. A simpatia por Naylor e a admiração pelo seu trabalho, compartilhada por Vinícius de Moraes e Aníbal Machado, estendia-se aos trabalhos de Misha, que recebeu elogios por parte da crítica na exposição "Monstros da Guerra”, realizada no Museu Nacional de Belas Artes, no centro do Rio.

Por conta do contato estreito que estabeleceu com a intelectualidade carioca, o casal acabou por servir de ponte para os demais "embaixadores da boa vontade" que visitariam o Brasil. Entre eles o próprio Orson Welles, que além de ter sido fotografado por Naylor na noite carioca, recebeu do casal Misha/Genevieve boas sugestões sobre locais aonde ir, na cidade do Rio de Janeiro, para filmar seu documentário sobre o Carnaval. Na correspondência com sua irmã Genevieve se gaba do seu conhecimento sobre as 'coisas' cariocas: "Welles conhece a Avenida Rio Branco e a Beira Mar, os tradicionais roteiros dos grandes desfiles de carnaval, mas não conhecia nada sobre a Praça Onze, onde acontece o verdadeiro carnaval negro carioca”.

O próprio Vinícius de Morais, cujo comentário sobre Naylor abre este estudo, foi um dos intelectuais brasileiros que freqüentaram o circuito carioca da Boa Vizinhança, cuja sociabilidade evidencia-se em uma outra de suas crônicas do período:

Ontem fui à Cinédia, a convite de Orson Welles, para vê-lo um pouco em ação. Anteontem o havia encontrado em Copacabana, e, como sempre acontece quan- 
do o encontro, toda a minha admiração e simpatia por ele se renovam. Discutimos, como também sempre acontece, numa roda onde se achavam entre outros amigos o pintor Misha e o escritor Aníbal Machado ... e dessa discussão nasceu o convite. Apressei-me a ir, naturalmente. ${ }^{19}$

Sediado no Rio, o casal realizou várias viagens pelo interior e para outras capitais brasileiras, entre elas São Paulo, Belo Horizonte, Recife, Maceió, Aracaju e Salvador. Em uma viagem mais extensa, iniciada em fevereiro de 1942, saiu do Rio diretamente para Belém do Pará, descendo pelo Nordeste e iniciando uma viagem pelo rio São Francisco, onde Genevieve dedicou-se a fotografar as pequenas e anônimas cidades do sertão. Em outra oportunidade viajaram para as cidades barrocas de Minas, e em Pirapora retomaram o São Francisco de barco. Em uma carta endereçada aos "Dearest Amigos Ruth e Caloca”, ${ }^{20}$ escrita em 1942, provavelmente dessa viagem de barco, Genevieve descreve as aventuras e desventuras do casal:

Esta viagem definitivamente não é de Pirapora (MG) para Joazeiro (PE), mas de um banco de areia para o próximo. A primeira vez que nós encalhamos (cerca de cinco minutos após o embarque) foi demais! — aqueles belos homens fortes e bronzeados, literalmente nos levantando dos bancos de areia - mas depois de passar um dia sem fazer nada, esperando pelo próximo banco de areia (com um pequeno problema de energia para completar), nós finalmente nos entregamos a Deus e a uma solitária garrafa do genuíno gim Gordon's com água tônica. O único problema é que temos um ilimitado estoque de água tônica, mas o gim parece evaporar-se, Deus sabe como!

Em outro trecho descreve as dificuldades de deixar o Rio, por conta dos passes para fotografar que deveriam ser emitidos pelo DIP:

O último dia no Rio foi um inferno na busca das cartas de apresentação, do passe do Lourival [Fontes] para poder tirar fotografias, e tentando enviar elefantes em caixas de sapato, tamanha era a tralha de última hora que conseguimos juntar. Finalmente conseguimos sair, na maior pressa, sem dar os últimos telefonemas, só para tomarmos nosso desastre de primeira classe, onde fomos espremidos até Belo Horizonte. Eu e Misha conseguimos as últimas camas, na última cabine do trem; enquanto matávamos o tempo tomando um drink no carro restaurante, o trem deu uma grande freada. Aí o pipi que eu havia decidido adiar, simplesmente não conseguiu esperar e eu voltei para a nossa cabine, 
encontrando tudo espremido feito uma sanfona, com todo o vapor das caldeiras bufando no meio das nossas camas. Bem, eu perdi quase dez quilos, nesse momento, suando só de pensar em todos os meus negativos (um ano inteiro de trabalho!) e os quadros de Misha derretendo atrás de nossas camas, onde os tínhamos guardado antes do desastre. Para completar o $f d p$ do condutor não parava de repetir: "bem, nós vamos deixar o carro aqui, vocês podem buscar suas coisas amanhã", e um outro $f d p$ nos xingando de quinta-colunas (traidores). Mas depois de alguns errr da minha parte, e outros tantos gestos de Misha, conseguimos retirar nossas bagagens em segurança e OK. Depois disso, Belo Horizonte foi um descanso e Pirapora uma pílula para dormir.

Durante o percurso o casal enfrentou uma série de contratempos devidos à ingerência do poder local, durante o Estado Novo. Desde a cobrança de taxas até salvo-condutos para fotografar eram exigidos em algumas localidades, e a fotógrafa teve seu equipamento apreendido inúmeras vezes, apesar do passe concedido por Lourival Fontes, chefe do DIP.

As imagens do Rio e das viagens que realizou pelo Brasil compõem um mosaico em movimento de Naylor. Um Brasil cuja cartografia afetiva revela a mistura, a polifonia das vozes que falam através das imagens de Naylor, numa intertextualidade que valoriza o poder da imagem nas suas múltiplas dimensões: poesia, publicidade, cinema e fotografia.

A poética visual de Naylor sintonizava com referências estéticas do pluralismo cultural, próprias do ambiente intelectual e artístico da Nova York dos anos 30. Entretanto dialogava também com a pedagogia do olhar própria a política implementada pelo CIAA.

\section{VisUALIZANDO A AMÉRICA LATINA}

Relembrando as motivações que o levaram a iniciar sua carreira como latino-americanista, o historiador norte-americano Frederick Pike confidencia:

nascido em 1926, eu comecei a me dar conta do mundo por volta dos anos 30, em parte, ouvindo o rádio ... Minha diversão radiofônica favorita eram as músicas estilo western do programa de Stuart Hamblen, a transmissão da lutas de Joe Louis e as conversar ao pé da lareira de FDR [Franklin Delano Roosevelt] ... Tomei conhecimento, vagamente, nos anos 30, que FDR tinha um especial interesse por certos vizinhos do sul chamados latino-americanos, e que ele havia 
iniciado um programa de Boa Vizinhança, através do qual esperávamos estabelecer melhores relações entre eles e nós ... aquilo soava como uma idéia bem decente. Naquela época muitas canções latinas estavam na moda ... os latinos me intrigavam tanto quanto os cowboys. No entanto, no final dos anos 30 , os latinos assumiram uma feição que não combinava com a dos cowboys: eles eram muito sexy. Dolores del Rio e Carmen Miranda nos municiaram de toda a prova de que necessitávamos. Obviamente FDR estava certo em esperar que os americanos se aproximassem dos latino-americanos. ${ }^{21}$

O relato das lembranças de Pike revela, com simpatia e bom-humor, como a fundação de um imaginário sobre a América Latina contou com dois ingredientes fundamentais: política e propaganda. O forte apelo político era encampado pelo próprio presidente Roosevelt, que apresentava os bons vizinhos latino-americanos nas suas conversas no rádio. Cabia aos meios de comunicação apresentar o perfil, criar um tipo latino-americano, visualizar a América Latina através de um conjunto de representações que dialogassem com a cultura visual do período, fortemente marcada pela crescente hegemonia das imagens técnicas: o cinema e a fotografia.

Em relação ao cinema, o investimento mais evidente e de maior vulto foi feito pelo governo, através de suas agências, entre elas o CIAA, em parceria com os grandes estúdios de Hollywood. ${ }^{22}$ Paralelamente, na mídia comercial foi implementado pelo CIAA um investimento significativo na produção de filmes de $16 \mathrm{~mm}$ voltado para a elaboração de uma imagem positiva das "outras repúblicas americanas”, como era denominada a América Latina na documentação oficial, dentro dos próprios Estados Unidos.

A produção de curtas para distribuição não comercial dentro dos Estados Unidos e na América Latina era apenas uma das muitas atividades da Motion Picture Divison (MPD). Criada como uma seção da Divisão de Comunicação, em outubro de 1940, a MPD foi entregue à direção de John Hay Whitney, que, além de ser amigo pessoal de Rockefeller, pertencia ao meio cinematográfico, sendo um dos produtores de E o vento levou. Além de assumir a direção da MPD, Whitney era vice-presidente o Museum of Modern Art de Nova York (MoMA), e presidente do Arquivo de Filmes do MoMA, e seus serviços eram doados ao governo na base de um-dólar-por-ano.

Por conta dessa ligação, a Biblioteca do MoMA, sob contrato com o CIAA, ficou encarregada de uma série de atividades associadas à distribuição dos filmes produzidos por esse órgão, para fins não comerciais. Entre elas se destaca a organização de catálogo, bem como a distribuição e a dublagem para o portu- 
guês e para o castelhano dos filmes sobre os Estados Unidos. Além disso, editava filmes e promovia a produção de filmes adequados ao quadro político.

Já como parte integrante da Divisão de Informação, depois que a de Comunicação foi extinta, a MPD era composta por um pessoal reduzido, sendo boa parte do trabalho realizado em parceria com a indústria cinematográfica. Tanto a produção de filmes comerciais como a de não comerciais eram gerenciadas pela mesma direção, que se dividia pelos dois escritórios, um em Washington e outro em Nova York. O primeiro ficava encarregado de estabelecer as diretrizes políticas do setor e coordenar o relacionamento com as demais agências governamentais; o de Nova York possuía atribuições executivas, sendo dividido em três seções:

1. Seção de Produção e Adaptação, responsável pela seleção, dublagem para o português e o castelhano e distribuição para a América Latina de material adequado produzido pelas demais agências governamentais, pela indústria cinematográfica e pela iniciativa privada em geral. Além disso, cabia a esta seção definir os temas, estruturar os roteiros e supervisionar a produção dos filmes de $16 \mathrm{~mm}$ pelos produtores independentes dos Estados Unidos.

2. Seção de Cinejornais, responsável pela inclusão semanal de assuntos relevantes para as relações interamericanas no circuito de cinejornais comerciais produzidos pelas grandes companhias, dentro e fora dos Estados Unidos. Durante o ano de 1942, através de acordos com as principais agências de cinejornais dos Estados Unidos - Paramount, Pathé, Universal, Fox-Movietone e News of the Day —, o CIAA conseguiu montar uma infra-estrutura de produção e distribuição de cinejornais sobre a América Latina. O primeiro projeto desta seção garantiu a cobertura completa da Conferência Pan-americana, realizada no Rio de Janeiro, entre os dias 15 e 28 de janeiro de 1942.

3. Seção de Distribuição, encarregada de organizar e supervisionar a distribuição de filmes de $16 \mathrm{~mm}$ em 'outras repúblicas Americanas' e averiguar se a embaixada norte-americana e os escritórios locais do CIAA possuíam equipamentos adequados para exibição e divulgação gratuita do material. Esta seção era também encarregada de distribuir, dentro dos Estados Unidos, filmes de interesse para a Política da Boa Vizinhança. No final do ano de 1943, cerca de 61 curtas, com temas ligados à guerra e às relações interamericanas, já haviam sido produzidos. 
$\mathrm{Na}$ avaliação do CIAA o grande investimento na produção de filmes estava vinculado à capacidade deste meio em atingir largas audiências, principalmente no caso da América Latina, onde boa parte do público alvo era analfabeto. Portanto, a educação visual fazia parte do projeto civilizatório com o qual os Estados Unidos se empenhavam em alavancar a América Latina do seu patamar de desenvolvimento. Um dos investimentos nesse sentido foi a organização de uma frota de 200 caminhões que percorriam as cidades do interior dos países da América Latina, para atingir pessoas que normalmente não iam ao cinema e, sendo assim, não eram atingidos pela propaganda do CIAA. No caso do Brasil, como aponta a documentação do CIAA, não foram enviados caminhões, somente 61 projetores de filmes de $16 \mathrm{~mm}$, indicando uma possível parceria entre o CIAA e o Governo Brasileiro. ${ }^{23}$

Em um pequeno catálogo intitulado The American Republics in Films: a List of $16 \mathrm{~mm}$. motion films on South and Central America and where they can be secured, publicado pelo CIAA, a importância política dos recursos audiovisuais fica evidenciada:

A futura paz mundial depende muito de quanto os povos de diferentes nações se conheçam. O Office of the Coordinator of Inter-American Affairs foi criado pelo governo dos Estados Unidos para promover e acelerar o entendimento entre os povos das nações do Hemisfério Ocidental. Um dos programas do Office está voltado inteiramente para a promoção, dentro dos Estados Unidos, do conhecimento sobre as demais Repúblicas Americanas. Centros Interamericanos foram criados para coordenar e reforçar regionalmente programas interamericanos, tanto nos aspectos culturais quanto nos comerciais. A ênfase recai sobre o uso dos recursos audiovisuais, notadamente, o cinema como uma eficiente e poderosa ferramenta educativa. A divisão de cinema ficou encarregada de divulgar filmes na América do Sul e Central, voltados para ensinar aos nossos vizinhos um pouco mais sobre os Estados Unidos. Da mesma forma, o Office está disponibilizando para audiências norte-americanas um crescente número de filmes voltados para a descrição dos costumes, estilo de vida, tradições, hábitos, educação, ciência e arte das demais Repúblicas Americanas. As páginas seguintes estão voltadas para a apresentação desses filmes a escolas, igrejas, clubes e grupos similares nos Estados Unidos, possibilitando-lhes um conjunto variado de opções. ${ }^{24}$

A iniciativa apontava o caminho de mão dupla na produção visual oficial. Se, por um lado, a nós, os latino-americanos, a pedagogia do olhar esta- 
ria voltada para o reconhecimento da supremacia comercial e cultural dos Estados Unidos, a eles seriam apresentados a nossa beleza cultural e o potencial para o progresso. Valorizava-se, através das imagens, a crença nos ideais da modernização técnica como progresso social, ao mesmo tempo em que se definia o lugar de cada país americano na geografia evolucionista das Américas. Não é sem propósito que em toda a documentação oficial do período a América Latina é referida pela expressão "demais Repúblicas Americanas".

Na quinta edição das Diretrizes e Sugestões para os Programas Interamericanos, também publicadas pelo CIAA desde 1940, mais uma vez reforçase a necessidade de disponibilizar um conhecimento maior sobre a América Latina para o público interno dos Estados Unidos, propondo uma estratégia que criasse um sentido de comunidade: "Como parte do processo de trabalho conjunto, nós dos Estados Unidos temos de conhecer mais sobre nossos vizinhos do sul — sua vida, sua cultura, suas aspirações e seu papel nesta guerra ... Ao se engajarem de coração nos ideais interamericanos de cooperação, grupos e organizações por todo o pais levantam a pergunta: Como podemos cooperar?".

Como resposta a essa demanda o CIAA preparou uma lista com dezoito tópicos - que iam desde o respeito às datas cívicas latino-americanas até a organização de eventos científicos e culturais, passando pelo ensino dos idiomas português e espanhol —, para ser distribuída em centenas de cidades nos Estados Unidos. Cada um dos 18 tópicos foi tratado separadamente, e em todos eles havia um item associado ao uso de imagens técnicas, tanto na forma de slides para ilustrar conferências, exposições de fotografias, divulgação de revistas com imagens sobre e América Latina, como na exibição de filmes documentários produzidos pelos órgãos oficiais, entre os quais destacavam-se CIAA, Pan American Union, Office of Education e American Council on Education.

O quarto item trata especificamente do uso de audiovisuais, especificando a necessidade de se estimular a exibição de filmes e slides sobre a América Latina:

The field of visual education offers one of the most effective means of reaching the American public. Much of Latin America can now be seen on the screen through a number of very interesting films available through the CIAA and through other sources.

$\mathrm{Na}$ área de educação os centros e grupos interessados em incentivar os programas de intercâmbio cultural entre as Américas investiram especifica- 
mente em: distribuir projetores para a exibição de filmes, publicizar o acesso de filmes e slides sobre a temática interamericana, encorajar o estabelecimento de cineclubes, criar um acervo de slides e incentivar sua utilização, bem como a de filmes nas escolas, e, finalmente, apoiar o trabalho de fotógrafos e cinegrafistas amadores que já tivessem viajado pela América Latina para exibir suas imagens.

Observa-se nas sugestões dadas um grande investimento na criação de uma comunidade imaginada, ${ }^{25}$ que compartilhasse de valores cívicos comuns e padrões de comportamento semelhantes. Nesse sentido, a eleição das escolas, bibliotecas, rádios comunitárias, clubes e igrejas, instâncias definitivamente ligadas à forte tradição associativa dos Estados Unidos, foi fundamental para elaborar uma esfera social de ação coletiva em prol do ideal comum de interamericanismo.

Entre os recursos destinados a promover a integração entre as Américas, a imagem técnica foi, portanto, fundamental, denotando o importante papel da cultura visual como forma de persuasão e de elaboração de conceitos e emoções. Através desse tipo de política cria-se uma demanda por imagens, na qual o papel de Naylor e dos demais fotógrafos associados ao CIAA é completamente justificado.

\section{UM MOSAICO EM MOVIMENTO:}

AS FOTOGRAFIAS BRASILEIRAS DE GENEVIEVE NAYLOR

Naylor não tinha muitos recursos técnicos à sua disposição: somente uma Rolleiflex e uma Speed Graphic, utilizando-se sempre de luz natural, sem filmes muito rápidos. No entanto, contava com algo que ela destacou como especial: a boa vontade dos brasileiros. Numa de suas cartas mencionou: "O que ajuda é a absoluta cooperação dos brasileiros. Eles são tão naturais, tão espontâneos e afetivos, que a câmera simplesmente os adora". ${ }^{26}$

Fotografia era para Naylor uma forma de expressar seu encantamento pelo mundo que a rodeava. $\mathrm{O}$ frescor das suas fotografias provinha do fato de que ela estava vendo tudo pela primeira vez. Ao contrário das fotografias teatralizadas do DIP, tipicamente de propaganda política, suas fotos registraram como o cotidiano poderia ser extraordinário. Ela achava os brasileiros simples e abertos, fáceis de lidar. Para uma estrangeira com uma grande câmera, com roupas estranhas e sem muita habilidade para se comunicar com pessoas que por sua vez também não tinham muito contato com o exterior, o re- 
sultado foi surpreendente. As pessoas fotografadas por Naylor ora aceitavam a sua presença, sem que esta atrapalhasse o que estavam fazendo, ora assumiam uma cumplicidade com a câmera, encontrando em Naylor uma presença amigável.

Convencida de que a espontaneidade era a melhor base para construir uma imagem, Naylor tinha uma estratégia para consegui-la, como explica Peter Reznikoff:

Como forma de capturar um momento composto, embora espontâneo, ela sempre procurou quebrar os padrões estáticos, posados, altamente estilizados que prevaleciam nos anos 20 e 30. Para isso, ela integrou a sua experiência enquanto fotojornalista na Associated Press, as fotos de Dorothea Lange, CartierBresson e o fervor artístico do realismo socialista e do impressionismo abstrato. Destilando o espírito dessas influências para criar um movimento consciente, um efeito de atualidade, ela teve que ser não apenas inventiva, mas esperta. Quando deparou com Red Skelton, bêbado, para uma sessão de fotos para a revista Good Housekeeping, ela o colocou em frente à televisão, ligou o aparelho e pediu que ele reagisse ao que estava vendo. O resultado energizou o palhaço Red Skelton, ao invés do bêbado Red Skelton. ${ }^{27}$

A estratégia de capturar a espontaneidade nas pessoas contribuiu para que as fotografias de Naylor celebrassem a força e a perseverança do povo, evitando enquadrá-los como exóticos. O olhar de encantamento que lançou para o Brasil, assim que chegou, não se perdeu ao longo dos quase três anos que permaneceu aqui. Suas viagens para o interior, juntamente com Misha, realimentaram essa impressão inicial, a cada novidade que o Brasil lhe apresentava.

As peregrinações de Naylor pelo Brasil seguem o mesmo rumo de outros viajantes ávidos pelo registro do novo, do incomum e muitas vezes bizarro. $\mathrm{O}$ Brasil, desde a abertura dos portos em 1808 por D. João VI, teve a sua paisagem redesenhada por riscadores que acompanhavam as expedições científicas, seguidos pelos fotógrafos paisagistas e, mais tarde, ao longo do século XX, por outros que buscavam o "resumo etnográfico" do país - apropriandome, aqui, da expressão de Aníbal Machado. Dentro dessa trilha passaram Gotherot, Verger e o próprio Lévi-Strauss. Para cada um as mediações que alimentavam a sua visualidade eram diferentes, mas cada qual buscava, à sua maneira, uma síntese original do país. Genevieve Naylor também buscou recriar o que via, a partir do que já tinha visto: o trânsito de pessoas por um 
país em crise, a afluência da sociedade de consumo de massa, as texturas do mundo fashion, enfim, os rostos e lugares com os quais compunha a sua linguagem fotográfica.

A presença da câmera era condição fundamental para a construção da memória, do registro ou da evidência. A natureza da produção visual variaria segundo o seu objetivo, mas a marca da originalidade de Naylor estava inscrita na sua própria maneira de olhar, como se evidencia numa carta para a irmã:

O meu primeiro impacto visual não foi a enorme energia da praia de Copacabana ou as avenidas e favelas, mas uma jovem negra sentada, em plena rua do centro, completamente concentrada na elaboração da sua flauta de madeira. Este é o momento em que gostaria de ter a minha câmera na mão! Infelizmente, as autoridades brasileiras confiscaram meu equipamento, enquanto vasculham meu passado para certificar-se de que não sou nenhuma quinta-coluna subversiva. ${ }^{28}$

Nas palavras da estudiosa Ana Lucia Gazolla,

Naylor resiste à apresentação de uma visão homogênea do país e recusa os estereótipos fáceis do paternalismo e do exotismo latino-americano ... Suas fotos buscam retratar uma realidade contraditória, múltipla, diversa, da qual nenhuma síntese é possível: nelas contracenam o rural e o urbano, cosmopolitismo e religiosidade tradicional, riqueza e miséria, desenvolvimento e atraso, uma sociedade em transformação que levará ao desaparecimento de comunidades culturais pela hegemonia de uma cultura urbana cosmopolita e excludente. Naylor focaliza o caráter multirracial da população brasileira e capta em imagens carregadas de uma extraordinária percepção as imensas contradições do país, contrariando os desejos da ditadura de Vargas e as expectativas do CIAA ... O país que retrata não é o das paisagens assépticas e des-historicizadas, nem o do desenvolvimento e do progresso absolutos, mas sim o do contraponto, da decalagem, do processo de modernização que acentua desigualdades. ${ }^{29}$

A avaliação de Gazolla sintetiza o resultado conquistado por Naylor, em suas andanças pelo Brasil. Uma leitura permeada pelo impacto que nos causa o conjunto da documentação fotográfica produzida por Naylor, considerada pelos estudiosos do período como a mais completa coleção sobre o Brasil da época, graças à natureza variada de suas imagens.

De acordo com o brasilianista Robert Levine (1998), mais de 1.350 fotografias sobreviveram ao tempo. Desse conjunto, o autor publicou, em livro or- 
ganizado com a colaboração de Peter Reznikoff, filho de Naylor, 101 imagens. Na sessão Photographs and Prints da Biblioteca do Congresso Norte-Americano, encontram-se arquivadas, na rubrica Archives of Hispanic Culture, cerca de 225 fotografias sobre o Brasil pertencentes ao CIAA; desse conjunto, 187 estão assinadas por Naylor, 10 seguem o mesmo estilo adotado pela fotógrafa, incluindo paisagens semelhantes, 24 são de Kidder Smith ou semelhantes ao seu tipo de fotografia, e as restantes seis imagens não foram identificadas.

Do conjunto de fotos guardadas na Biblioteca do Congresso, 37 encontram-se também no livro, as demais seguem o mesmo padrão estético e temático, com uma única diferença: as imagens arquivadas não foram editadas. Encontram-se fora do catálogo, numa espécie de miscelânea sobre a América Latina dos anos 40, sem tratamento especial. Todas estão coladas num suporte de cartão, com tamanho padrão de 24 x 18 (horizontais e verticais), identificação numérica no verso, carimbo do State Department, órgão ao qual o CIAA estava subordinado, e identificação do lugar e da data, todas de 1941. Todas estão assinadas pela fotógrafa, e do conjunto total somente nove não traziam identificação de data e local, as demais traziam uma breve legenda escrita em inglês, com a letra de Naylor. Acredito que o conjunto do trabalho de Naylor pode estar arquivado em diferentes lugares (além do material em posse do seu filho), juntamente com as demais imagens produzidas pelo CIAA. ${ }^{30}$

Para este trabalho reuni um conjunto de fotos encontradas na Biblioteca do Congresso dos Estados Unidos, as fotos publicadas no livro de Robert Levine e mais algumas encontradas no catálogo da exposição "Faces and Places in Brazil / Rostos e Lugares no Brasil", realizada na Pinacoteca do Estado de São Paulo, em novembro de 1994, sob a curadoria do filho de Naylor, Peter Reznikoff, somando um total de 264 fotos que analiso a seguir. ${ }^{31}$

A chave de leitura da mensagem fotográfica elaborada pela fotógrafa na sua produção brasileira evidencia-se no título da sua exposição no MoMA, em 1943, "Faces and Places in Brazil". A opção por valorizar as pessoas e lugares por onde andou vai fazer que todas as demais opções técnicas e estéticas fiquem por elas condicionadas. Vejamos como os quadros de significação visual se organizam na mensagem composta pelo conjunto das fotografias.

\subsection{O entramado visual}

As fotografias na sua absoluta maioria são grandes (máximo 24 x $20 \mathrm{~cm}$ e mínimo 15 x 16), retangulares, verticais e instantâneas. Padrão adequado ao tipo de aparato técnico que a fotógrafa utilizava, uma Rolleiflex e uma 4 x 5 
Speed Graphic, além de se alinhar às suas diretrizes de espontaneidade e movimento.

A visualização das imagens segue o padrão característico das revistas ilustradas, cuja leitura se processa da direita para a esquerda (44\%) e de forma nivelada ao plano do chão (50\%). No entanto, a incidência de tomadas de cima para baixo $(25,5 \%)$ e de baixo para cima $(24,5 \%)$ indica o diálogo entre as fotografias de Naylor e o cinema, principalmente com o jogo de câmera em Cidadão Kane, de Orson Welles. Em várias tomadas o rosto suado pelo calor do samba, ou os corpos sintonizados no ritmo do frevo, ganham movimento próprio ao acontecimento que está sendo registrado, apesar de a imagem ser fixa.

A distribuição de planos é fundamental para se avaliarem as relações entre o quadro e o fora de quadro, ou ainda, entre o conjunto de escolhas possíveis e as efetivamente realizadas. Nesse sentido, quanto maior a profundidade de campo, definida pela abertura do diafragma, maior seria a capacidade de colocar planos no foco, ampliando a possibilidade de integrar à imagem um conjunto significativo de informações. No caso da coleção analisada, a disposição dos planos foi a seguinte: $30 \%$ em um único plano; $46 \%$ com dois planos; $22 \%$ com três planos e $2 \%$ com quatro planos.

Num primeiro momento, avalia-se que a fotógrafa optou por uma profundidade de campo menor (76\% de fotos com plano único ou dois planos). Embora a luminosidade tropical lhe permitisse fechar mais o diafragma para conseguir um maior número de planos no foco, sua opção por valorizar a relação entre as pessoas e os lugares predominou, evidenciada na escolha da maioria das fotos com dois planos.

Entretanto, nessa distribuição, em $62 \%$ das fotografias a paisagem em conjunto com a figuração foram objeto central, valorizando a cena. Tal tendência se reforça ao aliarmos a opção dos planos com as de iluminação, contraste e distribuição dos elementos na foto. Nesse sentido, a incidência de $68 \%$ de fotos (a soma das fotos de 2, 3 e 4 planos), associada a uma opção por contrastes marcados por linhas retas bem definidas, equilíbrio entre claros e escuros, e entre a parte inferior e superior do quadro, busca construir uma composição na qual o conjunto é valorizado em consonância com suas partes, à maneira de um mosaico. É interessante perceber como a fotógrafa maneja bem suas escolhas técnicas e estéticas na produção de um sentido para o Brasil. Fotografam-se rostos sem desenraizá-los de seus lugares.

As fotografias de paisagem sem figuração não têm incidência, e as fotografias somente com figuração reúnem $33 \%$ das fotos e em geral são todas 
com um único plano. Isso evidencia que o objetivo da fotógrafa era criar uma imagem contextualizada, as pessoas no seu espaço social, ainda que valorizasse as representações do corpo, pelo alto índice de retratos.

John Pultz, em seu livro sobre a representação do corpo na fotografia, afirma: "Por mais de 150 anos a fotografia tem sido o mais difundido meio de comunicação visual, e contribui mais do que qualquer outra mídia para moldar as noções de corpo na sociedade contemporânea". ${ }^{32}$ Esse autor investiga como a representação fotográfica do corpo molda e reflete questões óbvias como identidade pessoal, sexualidade, gênero e orientação social, mas também, poder, ideologia e política.

Refletindo sobre o período no qual Genevieve Naylor se insere, aponta:

A fotografia nas décadas de 1930, 1940 e início de 1950 estava intimamente conectada com a Grande Depressão, a Segunda Grande Guerra e com os primeiros anos da Guerra Fria. Durante a primeira metade desse período, o corpo na fotografia foi principalmente retratado em temos de classe, raça e nacionalidade; somente mais tarde, a temática de gênero voltaria a ser considerada. ${ }^{33}$

A partir dessas considerações orientei minha abordagem, no sentido de definir a geografia social delimitada pelas fotos de Naylor, enfatizando o papel do retrato fotográfico na construção de uma alteridade social que busca dialogar com a condição humana dos sujeitos retratados.

A definição de retrato fotográfico não é tarefa fácil, ainda mais, no contexto da produção documental ou do fotojornalismo. John Tagg, em seus estudos sobre representação fotográfica afirma: "O retrato é um signo cujo objetivo é tanto descrever o indivíduo, como inscrevê-lo numa identidade social". ${ }^{34}$ Seguindo tal idéia, Grahan Clarke afirma que os retratos fotográficos, da mesma forma que os pintados, conferem status ao indivíduo retratado e tornam pública a presença de sua personalidade..$^{35}$

Em linhas gerais, na literatura técnica, o que realmente define o retrato na fotografia é o senso de individualidade e de diferença que a imagem expressa. Não basta enquadrar um rosto, ou uma pessoa, é necessário distinguila das demais, da multidão, atribuir-lhe um valor que, ao mesmo tempo, a diferencia como um ser humano, a identifica como um sujeito social. Ao comentar as imagens do fotógrafo alemão August Sander, Grahan esclarece esse duplo processo:

Definidos por possuir (ou não) uma profissão, eles tomam seu lugar na densa hierarquia de sentido estabelecida através da distinção e da diferença social ... 
Neste sentido, a figura se credencia pela sua posição relativa, elas existem por serem diferentes, e não semelhantes às demais figuras. O indivíduo se constrói em função de uma identidade social mais ampla — não pelo nome, mas pela ocupação: um lutador, um comerciante, um padeiro, um cozinheiro, um advogado etc. Nos retratos de Sander todos os detalhes são significativos — tudo faz sentido, mas nós temos de investigar para encontrar todo o possível traço, pista de uma existência própria. É a sociedade que se mostra - no espaço público a existência individual só faz sentido se tem acesso a este mesmo fórum. ${ }^{36}$

As fotos de Sander, ao contrário das clássicas fotos de Walker Evans, para exemplificar com um grande nome da fotografia documental norte-americana da mesma época, mostram mais do que revelam uma face em qualquer contexto público. A diferença entre mostrar e revelar, ou entre fazer uma foto e tirar uma foto, implica a negociação, entre o fotógrafo e o fotografado, do valor atribuído à pose, implica um confronto de olhares, implica a construção de uma relação social diferente da que se estabelece entre a fotografia-denúncia e o retrato consentido.

O retrato pode ser só de rosto ou de corpo inteiro; quanto mais partes desse corpo ficarem expostas, tanto maior será a possibilidade de historicizála. Todos os atributos relacionados ao corpo são, portanto, definidos historicamente através de práticas culturais e sociais concretas: indumentária, higiene, alimentação etc. Os retratos de Genevieve Naylor produzidos no Brasil traduzem o diálogo da fotógrafa com a pauta social do seu tempo, pois se orientam nos temas de classe, raça e geração. Tais considerações são confirmadas na avaliação dos tópicos relacionados aos espaços da figuração, geográfico e das vivências e experiências retratadas.

Os locais fotografados revelam as duas diretrizes que orientaram o trabalho da fotógrafa, ora como funcionária do CIAA, ora como uma profissional sensível e comprometida com as demandas sociais. Cerca de $41 \%$ das fotografias são do Rio de Janeiro, desse conjunto somente 15\% são do subúrbio da cidade e 3,5\% da zona rural do Estado. De outros estados, ainda dentro da pauta definida pelo Estado Novo, consta uma série de 15 fotografias tiradas em escolas de Belo Horizonte, cuja estética se aproxima das fotografias produzidas pelo Ministério da Educação e Saúde de Vargas. Nestas as crianças aparecem fazendo exercícios, em forma, estudando, alimentando-se, enfim, um culto à formação do cidadão brasileiro.

As demais imagens mostram os caminhos trilhados pela fotógrafa nas suas viagens e as marcas que definiu como relevantes para configurar a espe- 
cificidade do Brasil. Desse conjunto 12\% são de fotografias de cidades do interior sem identificação específica de local, 11,5\% são das cidades históricas de Minas Gerais - Ouro Preto e Congonhas do Campo, nas festividades da Semana Santa —, 15\% são imagens de cidades ribeirinhas do São Francisco, nas quais se busca a espontaneidade de um cotidiano marcado pela precariedade.

Os atributos da paisagem são objetos que qualificam as condições de vida de cada espaço. Nesse sentido, o espaço urbano dos grandes centros está associado a objetos que denotam o consumo e a vida agitada das metrópoles: outdoors, prédios, entulhos, postes, calçadas, tapumes, fios, vitrines, toldos, estátuas, bondes, carros, trens etc. A zona rural recebe atributos próprios, tais como: casas de pau-a-pique, canoas, vegetação agreste, roupas estendidas ao sol, redes, utensílios de palha, numa economia que reforça o sentido de precariedade e a oposição entre interior e litoral, ou ainda, entre o Brasil urbano-industrial que teria condições para integrar o concerto das nações civilizadas e o Brasil agrário e latifundiado, preso ao passado colonial a ser superado.

$\mathrm{Na}$ construção do espaço da figuração o espaço coletivo teve maior incidência que o individual, o masculino sobre o feminino, o adulto em relação ao infantil. Mesmo assim, a presença significativa de crianças, quer acompanhadas de adultos, quer sozinhas ou reunidas em grupo (34\%), aponta para uma crescente preocupação com a condição infantil, já evidenciada na pauta do projeto da Farm Security Administration (FSA), e ainda hoje presente nas fotografias de documentação social de Sebastião Salgado, por exemplo.

Outro dado a ser considerado é a questão da raça. É evidente o interesse da fotógrafa pela situação do negro no Brasil, tanto que suas fotos não foram bem aceitas pelas autoridades sediadas na cidade do Rio de Janeiro. "Há muito mais no Brasil que sacolejos de negros, negros no Carnaval, instituições religiosas e bricabraque", disse o principal dirigente do comitê carioca do CIAA ao recusar para exposição os trabalhos da fotógrafa norte-americana. ${ }^{37}$

É interessante notar que o debate racial no Brasil, nessa época, matiza seus contornos eugenistas pela valorização do nacional-popular e com ele da cultura negra, principalmente o Carnaval. Com certeza nas conversas que Genevieve Naylor travou com os intelectuais brasileiros esse tema entrou em pauta. Conversando com Vinícius de Moraes, por exemplo, este poderia ter argumentado: "Nosso negro é um valor excelente, e de grande expressão. Não há razão para escondê-lo, criando-se a impressão de que temos um preconceito que não cabe a nossa natureza de povo americano" ( $A$ Manhã, 30.4.1942).

As pessoas, seus rostos e corpos, estão presentes em praticamente todas as fotografias de Naylor. Como seu princípio é o da espontaneidade, daí o 
grande número de fotos instantâneas, a mise-en-scène da pose foi completamente definida pela valorização do movimento. Em 18\% das fotos as pessoas posam para a fotógrafa, nas demais ela as retratou dançando, caminhando, trabalhando, tocando instrumentos, divertindo-se, na procissão, exercitandose, jogando bola, tomando banho de mar — vivendo, enfim.

A construção da cotidianidade também marcou a variedade da pauta temática, que, associada às opções de enquadramento aqui já apontadas, possibilitou construir um quadro do Brasil que buscava incluir o máximo de aspectos da sua natureza diversa e contraditória. No conjunto de fotografias os temas variaram do retrato de Vargas, nas vitrines das lojas de retratos e nas paredes dos bares populares (três fotos), até as imagens do dia-a-dia na pequena cidade debruçada sobre o rio São Francisco (47 fotos), passando pela Princesinha do Mar e seus diversos contornos, do amanhecer com os pescadores ao entardecer com as garotas 'chics' em frente ao Copacabana Palace (19 fotos), pelos clubes exclusivos, culminando na apoteose carnavalesca (32 fotos). Sem deixar de mostrar o trabalho (20 fotos) e a educação (série produzida em uma escola em Belo Horizonte, com 16 fotos), como respostas necessárias à demanda oficial de imagens.

Os protocolos de visualidade definidos pelo CIAA deveriam ser compartilhados pelo conjunto de seus representantes, nas suas viagens pelas 'demais Repúblicas Americanas'. Logo depois de retornar de seu tour da Boa Vizinhança, Walt Disney produziu Alô Amigos (1943), um simpático desenho animado, no qual se relatou em cores variadas e tons fortes o passeio dos desenhistas na busca da imagem ideal da América Latina. Para cada país buscou-se um equivalente, um semelhante, para dar sentido a essa comunidade imaginada que se buscava forjar entre as Américas. Em cada país, também a alteridade era definida pela estética do pitoresco. As imagens de Disney perseguem o padrão da dicotomia que diferencia 'nós' dos 'outros'.

Comparando as fotografias produzidas por Genevieve Naylor com esse padrão, evidenciam-se algumas semelhanças, em respeito à diretriz imposta, mas também se descobre um conjunto de imagens que apontam para certa porosidade dos processos hegemônicos. Onde se quer a homogeneidade do típico, Naylor traz a diversidade do que é próprio a cada lugar. Como comentava Anibal Machado: "Nada de cachoeiras". 


\section{A TRAJETÓRIA DAS IMAGENS}

Genevieve Naylor retorna aos Estados Unidos em agosto de 1942. Durante os meses de janeiro e fevereiro de 1943, 50 de suas fotografias sobre o Brasil foram exibidas na exposição chamada "Faces and Places in Brazil". A imprensa norte-americana a anunciou como complemento à exposição "Brazil Builds", organizada com as fotografias de Kidder Smith, e ambas viajaram pelos Estados Unidos, dentro do marco da aproximação entre os dois países.

\section{Mais sobre o Brasil}

O Museu de Arte Moderna suplementando a sua grande exposição sobre arquitetura brasileira, "Brazil Builds", instalou num estreito corredor da galeria do térreo uma mostra de cinqüenta fotografias de Genevieve Naylor, intitulada "Faces and Places in Brazil". Um excelente pano de fundo para a exposição principal.

O trabalho de câmera é claro, simples e direto e revela que no Brasil existem jogos e bondes superlotados, belas garotas e teatro de marionetes, festivais e lanches gratuitos nas escolas, e o transporte fluvial tem um importante papel na vida do interior do país. Além disso, apresenta um número de fotografias de fachadas de edifícios que nos faz lembrar a tradição hispânica.

Miss Naylor trabalhou na América do Sul, sob os auspícios do Coordinator of Inter-American Affairs, do outono de 1940 até o último agosto. Sua exposição continuará conjuntamente com a "Brazil builds" até 28 de fevereiro. Ambas circularão posteriormente por outras cidades do país.

(Edward Alden Jewell, New York, NY Times, 27.Jan.43)

Os comentários sobre as fotografias de Naylor apontam para a forma de recepção das imagens por parte do público norte-americano, evidenciando também o conteúdo de propaganda das imagens veiculadas. Das 50 imagens exibidas, a que foi reproduzida em vários jornais mostrava o bonde de São Januário, subúrbio carioca, completamente lotado, reforçando a comunidade imaginada entre as cidades brasileiras e norte-americanas:

O bilhete, por favor - então você pensa que os bondes e ônibus de Pittsburgh estão superlotados? Aqui está um bonde na hora do rush no Rio, Brasil, outro país onde o presidente Roosevelt parou na sua volta de 
Casablanca. Esta foto é uma das 50 exibidas sobre o Brasil, na mostra do New York Museum of Modern Art. (Sun Telegraph, Pittsburgh, PA, 29.Jan.1943)

Pensa que você está sozinho? Se é uma das pessoas que reclamam dos transportes coletivos entupidos, veja só o que acontece no Rio de Janeiro, em plena hora do rush. Aliás, esse é o título da foto exibida na mostra de 50 fotografias de Genevieve Naylor, "Faces and Places in Brazil", apresentada no NY MoMA. (Time \& News, 3.Feb.1943)

Hora do rush: um acolhedor passeio num bonde na capital do Brasil.

Passageiros espremidos dentro de um bonde no Rio de Janeiro, não parecem tão aborrecidos como os nossos. Essa é uma das 50 fotografias de Genevieve Naylor em exibição no NY MoMA. (Hopkinsville, KY, New Era, 5.Feb.1943)

Entre 1943 e 1944 as fotografias de Naylor viajaram pelos Estados Unidos: Boston, Rochester, Colorado Springs, São Francisco e por toda a Costa Oeste, traçando um percurso onde as possibilidades de recepção eram orientadas por comentários como os aqui expostos. A idéia de uma identificação entre os dois países está na base da doutrina da Boa Vizinhança. Apesar das diferenças evidenciadas nas imagens, ambos fazem parte da mesma cultura ocidental, e se os norte-americanos sobreviveram à Grande Depressão, os brasileiros também conseguiriam se modernizar e integrar-se à comunidade democrática e liberal.

Na mesma época em que a exposição de Naylor viaja pelos Estados Unidos, o CIAA elabora seu relatório sobre as atividades no ano de 1943. Em compasso com as imagens que seguem o seu rumo país adentro, em consonância com as diretrizes de divulgação da imagem das 'demais repúblicas americanas', definidas pelo mesmo órgão, o relatório radiografa um país cujas potencialidades não podem passar despercebidas pelo governo dos Estados Unidos. Evidencia-se na leitura do relatório a presença contraditória dos dois Brasis apresentados por Naylor: o crescimento urbano e a potencialidade dos recursos naturais, em contraste com a estrutura agrária ultrapassada e obsoleta, aliada à total falta de infra-estrutura para o desenvolvimento industrial.

Não há evidências explícitas de que o CIAA tenha feito uso técnico das fotografias de Naylor; no entanto, a sintonia entre o aspecto descritivo das imagens e do relatório é impressionante. Em ambos, cada qual à sua maneira, estão caracterizadas as contradições que definiam o Brasil de então, apon- 
tando para o fato de que além de representar modos de vida e marcas simbólicas, as fotografias apresentam evidências materiais que servem também para a construção de um discurso técnico.

Depois da sua exposição no MoMA de Nova York, as fotografias de Naylor serviram para compor reportagens sobre as relações interamericanas no período. Uma delas, publicada na "Sunday Mirror Magazine Section" do New York Sunday Mirror, em 18 de abril de 1943, intitula-se: "The Brotherhood of the Americas". Nessa reportagem a foto de Naylor, uma vista do calçadão da Praia de Copacabana, na direção do bairro de Leme, enquadra no primeiro plano caminhando no calçadão um padre de batina e, logo atrás, uma jovem empurrando um carrinho de bebê; no segundo plano a curva da praia, com a Pedra do Leme ao fundo. A foto valoriza a cena com os seus personagens, pessoas comuns caminhando em Copacabana, num dia ensolarado qualquer.

A legenda da foto esclarece a sua escolha pelo editor da seção:

No dia do Pan-Americanismo nós homenageamos os mais antigos e bem-sucedidos governos soberanos na terra - mensagem de FDR em 14 de abril de 1942. Esse sucesso reflete-se na beleza e dignidade da vista majestosa do Rio (acima) - foto de Genevieve Naylor, com autorização do Museum of Modern Art.

Logo no início da reportagem, assinada por Nelson Rockefeller, identificado como o Coordinator of Inter-American Affairs, entre parênteses, celebra-se a entrada do hemisfério na segunda década da Política da Boa Vizinhança. Esta é definida como uma prova tangível de que nações livres e soberanas podem trabalhar juntas em prol de uma mesma causa, a proteção da liberdade, da dignidade e do bem-estar de seu povo, promovendo a paz com justiça e decência. As palavras de Rockefeller ganham materialidade através da fotografia escolhida: As opções de luz, definição dos claros e escuros, do foco, e a distribuição dos elementos na foto valorizam o conjunto da cena, permitindo uma leitura clara e direta da imagem. Ao mesmo tempo, as opções pelo sentido vertical e pelo direcionamento das linhas de composição da direita para a esquerda sugerem estabilidade e equilíbrio, na valorização da cena em conjunto. Reforçando essas idéias, a figuração representada pela religião e pela família, bastiões da decência. Os diferentes usos da fotografia de Naylor revelam a capacidade polifônica da imagem fotográfica, bem como a estreita relação entre imagem e o meio no qual ela está sendo veiculada, na definição do sentido atribuído às imagens.

Não só as imagens de Naylor contribuíram para dar subsídios ao discurso oficial, mas também as dos demais fotógrafos e documentaristas que atua- 
ram aqui, no período da Boa Vizinhança, reforçando, com isso, o papel desempenhado pelas imagens técnicas na produção de sentido social.

\section{CONCLUSÃO}

Depois da guerra Naylor passa a trabalhar nas principais revistas de moda norte-americanas, entre elas a Harper's Bazaar, onde teve como mentor Alexy Brodovich. Aos poucos especializa-se na modalidade retrato, tornando-se fotógrafa de celebridades, entre as quais a primeira dama norte-americana, Eleanor Roosevelt. Por toda a sua vida, Naylor manteve contato com a comunidade artística brasileira em Nova York, e com as referências de vocabulário que aprendeu no Brasil. Como relembra Peter Reznikoff:

Meus pais sempre falavam com muito carinho do Brasil, eles até se comunicavam em português, quando não queriam que eu e meu irmão entendêssemos o que eles estavam conversando. Isso ajudou muito durante o final dos anos 50 e ao longo dos anos 60, quando a Bossa Nova explodiu nos Estados Unidos. Eles recebiam e hospedavam uma porção de músicos que aqui chegavam do Brasil. Eles eram próximos do Stan Getz, responsável por produzir a música brasileira nessa época, e até apresentaram a ele vários músicos brasileiros, entre eles Luis Bonfá, Jobim e [João] Gilberto, entre outros. ${ }^{38}$

Apesar de ter trabalhado durante toda a sua vida como fotógrafa, somente nos anos 90, graças a um empenho de seu filho, as imagens brasileiras de Genevieve Naylor, falecida em 1989, aos 74 anos de idade, ganharam notoriedade, permitindo que tivéssemos acesso a um olhar mais sensível, complexo e sofisticado, no âmbito da Política da Boa Vontade. Naylor foi capaz de ver para além dos estereótipos e imagens pasteurizadas da época.

\section{NOTAS}

${ }^{1}$ Este trabalho integra o projeto de pesquisa "Memórias do contemporâneo: narrativas e imagens do fotojornalismo do Século XX”, com financiamento do CNPq, 2005-2008; contou com a participação na pesquisa e no tratamento das fotos da graduanda Ana Paula da Rocha Serrano.

${ }^{2}$ Professora adjunta do Departamento de História da Universidade Federal Fluminense (UFF) e pesquisadora do Laboratório de História Oral e Imagem da UFF. 
${ }^{3}$ Sobre o papel desempenhado pelas imagens técnicas na Política da Boa Vizinhança ver: MAUAD, A. M.: A América é aqui: um estudo sobre a influência cultural norte-americana no cotidiano brasileiro (1930-1960). In: TORRES, S. (Org.) Raízes e rumos: perspectivas interdisciplinares em estudos americanos. Rio de Janeiro: 7Letras, 2001, p.134-46; e MAUAD, A. M. As três Américas de Carmem Miranda: cultura política e cinema no contexto da Política da Boa Vizinhança. In: Transit Circle: Revista Brasileira de Estudos Americanos, Rio de Janeiro: ABEA/Contra-Capa, v.1, Nova Série, 2002, p.52-77.

${ }^{4}$ Sobre a Doutrina do Destino manifesto e a política moral norte-americana ver, DONOGHUE, D.: Os verdadeiros sentimentos da América, p.216-32; e CHACE, J.: Sonhos de perfectibilidade: a excepcionalidade americana e a busca de uma política externa moral, p.23344; In: DONOGHUE, D. et al., A América em teoria. Rio de Janeiro: Forense Universitária, 1993.

${ }^{5}$ Ver a documentação sobre as exposições e atividades do MoMA no Archives of American Art, seleção de clippings, microfilme números AAA5069; AAA 5056; AAA 5093; AAA 5066.

${ }^{6}$ MOTA, C. G. Cultura e Política da Boa Vizinhança: dois artistas norte-americanos no Brasil. In: COGGIOLA, O. (Org.) Segunda Guerra Mundial: um balanço histórico. São Paulo: Xamã/FFLCH/USP, 1995, p.493.

${ }^{7}$ Ibidem.

${ }^{8}$ Ibidem, p.494.

${ }^{9}$ TOTA, P. A. Imperialismo sedutor. São Paulo: Companhia das Letras, 2000.

${ }^{10}$ MOURA, G. Tio Sam chega ao Brasil: a penetração cultural americana. São Paulo: Brasiliense, 5.ed., 1988, p.7-12.

${ }^{11}$ TRACHTENBERG, A. Reading American Photographs: Image as History, Mathew Brady to Walker Evans. New York: Hill and Wang, 1989.

${ }^{12}$ PIKE, F. B. The United States and Latin America: Myths and Stereotypes of Civilization and Nature. Austin: University of Texas Press, 1992, p.294.

${ }^{13}$ Concerned Photographs é o termo que designa a produção de imagens fotojornalísticas, com forte apelo social, a partir da década de 1930, com a criação das agências fotográficas, compostas por fotógrafos independentes. Entre as mais famosas do século XX estão a Dephot, criada por Eric Solomom em 1930, a Magnum, criada por Robert Capa, em 1947. Para uma informação resumida acesse: www.comciencia.br/reportagens/memoria/12.shtml.

${ }^{14}$ A reprodução do documento pode ser encontrada no livro publicado por Robert Levine com a colaboração de seu filho Peter Reznikoff. LEVINE, R. M. The Brazilian Photographs of Genevieve Naylor. 1940-1942. Durham and London: Duke University Press, 1998.

${ }^{15}$ Carta, Genevieve Naylor para Cynthia Gillipsie, Rio de Janeiro, c. Dezembro 1941, cortesia Cynthia Gillipsie, cit. LEVINE, op. cit., p.2. 
${ }^{16}$ Suas imagens estão arquivadas no National Archives, USA, e possivelmente também na Fiocruz.

${ }^{17}$ DIP, Divisão de Turismo. “Assuntos que devem ser fotografados no Rio de Janeiro”, c.1941, cortesia de Peter Reznikoff, cit. LEVINE, op. cit., p.38.

${ }^{18}$ Citado por MOTA, C. G, op. cit., p.496. Infelizmente o texto de Mota não contém as referências documentais de onde a citação foi retirada, impossibilitando-nos a consulta da fonte primária de informações.

${ }^{19}$ A Manhã, 30.04.1942.

${ }^{20}$ Sob a guarda de seu filho Peter Reznikoff.

${ }^{21}$ PIKE, Frederick, 1996, p.xv.

${ }^{22}$ Sobre a relação entre imagem cinematográfica e Política da Boa Vizinhança ver: WOLL, A. L. The Latin Image in American Films, revised edition, Los Angeles: UCLA Latin American Center Publications, 1980; LOPEZ, A. M. Are all Latins from Manhattan? Hollywood, ethnography and cultural colonialism. In: LOPEZ, A. [et al.] Mediating two worlds: cinematic encounter in the Americas. London: Verso, 1993; MENDONÇA, A. R. Carmen Miranda foi a Washington, Rio de Janeiro: Record, 1999; MAUAD, A. M. A América é aqui: um estudo sobre a influência cultural norte-americana no cotidiano brasileiro (19301960). In: TORRES, S. (Org.) Raízes e rumos: perspectivas interdisciplinares em estudos americanos, Rio de Janeiro: 7Letras, 2001, p.134-46. MAUAD, A. M. As três Américas de Carmem Miranda: cultura política e cinema no contexto da Política da Boa Vizinhança. In: Transit Circle: Revista Brasileira de Estudos Americanos, Rio de Janeiro: ABEA/ContraCapa, v.1, Nova Série, 2002, p.52-77; FREIRE-MEDEIROS, B. The Travelling City: U.S. Representations of Rio de Janeiro in Films, Travelogues and Schorlarly writing (1930s-1990s), Tese (Doutorado), Binghamton University, State University of New York, 2002; FREIREMEDEIROS, B. Diplomacia em celulóide: Walt Disney e a Política de Boa Vizinhança. In: Transit Circle: Revista Brasileira de Estudos Americanos, Rio de Janeiro: ABEA/ContraCapa, v.3, Nova Série, 2004, p.60-79.

${ }^{23}$ ROWLAND, D. W. A History of the Office of the Coordinator of Inter-American Affairs. Washington, D.C., 1946.

${ }^{24}$ The Library of the Congress Serial Record, mar 24, 1944 (copy Govt. Source).

${ }^{25}$ ANDERSON, B. Imagined Communities: reflections on the origins and spread of nationalism, London/New York: Verso, 1991. O sentido de compartilhamento de valores culturais estaria na raiz dos movimentos nacionalistas oitocentistas, segundo o autor. Apesar de efetivamente a idéia de inter-americanidade não coadunar com as propostas nacionalistas do contexto da Política da Boa Vizinhança, o investimento simbólico apontado garantiria ao menos a possibilidade de um patamar cultural comum, a partir do qual as trocas políticas se efetivariam.

${ }^{26}$ Citado em LEVINE, op. cit., p.36. 
${ }^{27}$ Citado em MOTA, C. G., Catálogo da exposição Genevieve Naylor, Faces and Places in Brazil, Pinacoteca (SP), nov. 1994, p.12.

${ }^{28}$ Carta de Genevieve Naylor para Cynthia Gillipsie, Rio de Janeiro, s.d., sob a guarda Peter Reznikoff. Citado em LEVINE, op. cit., p.36.

${ }^{29}$ Trecho retirado do Folder da exposição "Cenas do Brasil”: GAZZOLA, A. L., O olhar de uma boa vizinha: as fotos brasileiras de GN. (Folheto da Exposição "Cenas do Brasil”, Genevieve Naylor, fotografias.)

${ }^{30}$ No National Archives existe uma coleção Nelson Rockefeller, além do material visual que foi produzido pelo CIAA: propaganda, material fílmico e cartazes resultantes de um concurso realizado em 1940 que envolveu vários concorrentes da América latina. Sobre esse material ver em Archives of American Art, microfilmes contendo os clippings no MoMA, além dos próprios arquivos do órgão no National Archives.

${ }^{31}$ Sobre análise histórico-semiótica que desenvolvo ver: MAUAD, A. M. Sob o signo da imagem: a produção da fotografia e o controle dos códigos de representação social pela classe dominante na cidade do Rio de Janeiro, 1900-1959. Niterói: UFF, LABHOI, www.uff.história.br/labhoi (link publicações) e MAUAD, A. M. Fotografia e história, possibilidades de análise. In: CIAVATTA, M. e ALVES, N. (Org.) A leitura de imagens na pesquisa social. História, comunicação e educação. São Paulo: Cortez, 2004, p.19-36.

${ }^{32}$ PULTZ, J. The Body and the Lens: photography 1839 to the present. New York: Harry N. Abrams, Inc., 1995, p.7.

${ }^{33}$ Ibidem, p.89.

${ }^{34}$ TAGG, J. The Burden of representation. London: Verso, 1988, p.37.

${ }^{35}$ CLARKE, G. The portrait in Photography. In: The Photograph. New York/Oxford: Oxford University Press, 1997, p.102.

${ }^{36}$ Ibidem, p.113.

${ }^{37}$ Memorando da Divisão Brasileira do CIAA para Francis Alstock, Rio de Janeiro, 11.8.1942, Arquivos CIAA, National Archives, Washington, citado em MENDONÇA, A. R. Carmem Miranda foi a Washington, op. cit., p.89.

${ }^{38}$ Entrevista por e-mail em 5.1.2004. 